\title{
Identification of bacterial leaf blight resistance genes in Malaysian local rice varieties
}

\author{
N.A. Hasan ${ }^{1,2}$, Mohd Y. Rafii ${ }^{1,3}$, Harun A. Rahım ${ }^{4}$, F. Ahmad ${ }^{4}$ and \\ N. Nik Ismail ${ }^{2}$ \\ ${ }^{1}$ Institute of Tropical Agriculture and Food Security, Universiti Putra \\ Malaysia, Serdang, Selangor, Malaysia \\ ${ }^{2}$ Faculty of Applied Sciences, Universiti Teknologi MARA, Cawangan \\ Negeri Sembilan Kampus Kuala Pilah, Negeri Sembilan, Malaysia \\ ${ }^{3}$ Department of Crop Science, Universiti Putra Malaysia, Serdang, Selangor, \\ Malaysia \\ ${ }^{4}$ Agrotechnology \& Bioscience Division, Malaysian Nuclear Agency, \\ Kajang, Selangor, Malaysia \\ Corresponding author: N.A. Hasan \\ E-mail: aishahnh@uitm.edu.my
}

Genet. Mol. Res. 19 (3): gmr18545

Received April 24, 2020

Accepted July 03, 2020

Published August 30, 2020

DOI http://dx.doi.org/10.4238/gmr18545

ABSTRACT. Xanthomonas oryzae pv oryzae (Xoo) is a bacterial pathovar that causes a serious bacterial leaf blight disease of rice. This disease poses significant constraint on food security in Asia, as it causes yield loss in rice. There is an urgent need to control bacterial blight disease through resistance cultivars. However, the genetic potential of Malaysian rice cultivars has not been explored. We screened 10 cultivated Malaysian varieties with high yield performance for resistance genes using three simple sequence repeat and two sequence tagged sites markers coupled with phenotypic screening. All 10 rice genotypes were found to carry $x a$ recessive gene. Four genotypes had two resistance genes tightly linked with the specific markers; Mahsuri Mutant carried the dominant resistance genes, $x a 4$ and $x a 2$ whereas NMR152 and the Tongkat Ali mutant had the dominant genes, $x a 21$ and $x a 2$. However, $x a 13$ and $x a 5$ resistance genes were not detected in this Malaysia rice germplasm group. In a greenhouse assessment, genotypes carrying more than a single resistance gene were found to be resistant against Xoo 
MXO 1410 isolates. These cultivars have potential as genetic materials for rice quality breeding programs.

Key words: Malaysian rice; SSR marker; STS marker; Xanthomonas oryzae pv oryzae; $x a$ gene

\section{INTRODUCTION}

Rice (Oryza sativa) is a primary food source for 3.5 billion people in the world, and Asia is the top rice consuming and producing continent (Herman et al., 2015). Rice is classified as a principal crop with regards to cultivation area and production in Malaysia (Wahab, 2018). The rapid growth of the human population in Asia has led to an estimation of about $70 \%$ rice production increase needed to meet future demands (Rajamoorthy et al., 2015).

Annually, biotic stresses (weeds, insect pests and pathogens) contribute to the world's rice crop losses (Patra et al., 2016). Among these, Xanthomonas oryzae pv. oryzae (Xoo), the causative agent of bacterial leaf blight disease, considered the oldest and most important disease of rice (Chukwu et al., 2019). In 1884, farmers in Japan first recognized this disease (Tagami and Mizukami, 1962). In Malaysia, the infection was first noticed on a small scale in the early 80s rice fields of Peninsular Malaysia (MOA, 2018). Previously, this disease had spread more vigorously where $10-20 \%$ crop losses were observed under moderate prevailing conditions, whereas under conducive conditions, up to $50 \%$ crop losses were recorded. In recent years, an increase in bacterial leaf blight attack was recorded in 12,080 hectare rice-growing areas in Peninsular Malaysia including Selangor (5,945 ha), Kedah (4,415 ha), Pulau Pinang (620 ha), Terengganu (440 ha), Negeri Sembilan (291 ha), Perak (174 ha), Pahang (46 ha), Perlis (141 ha), Johor (5 ha), Kelantan (1 ha), and Melaka (less than 1 ha) (DOA, 2019).

Various chemical and cultural approaches have been used for the management of bacterial leaf blight. However, this use is limited because the technique is relatively time consuming and laborious. Host resistance is the most favored approach to manage the bacterial pathogen, Xoo by developing durable BLB-resistant cultivars (Vikal and Bhatia, 2017). However, the durability of plant resistance has often been limited and some varieties was broken down within several years. Therefore, resistance breeding requires continuous efforts to evaluate the diversity within the germplasm for details of genes. Artificial inoculation method to screen the resistant variety are always recommended and ideal because disease symptom develop quickly.

Advances in DNA marker technology have sped up the identification of resistant cultivars carrying resistance gene(s) (Nor'Aishah et al., 2013). Till now, about 34 genes (23 dominants and 16 recessive genes) conferring resistance to bacterial leaf blight have been identified (Zhou, 2019). By using DNA markers, numerous commercial rice varieties have been introgressed with race-specific resistance genes including $x a 4, x a 5, x a 7, x a 13$, and $x a 21$ and improved their resistance against Xoo (Bharani et al., 2010). SSR markers have been commonly used as they are highly informative, easy to use and cost effective (Nadeem et al., 2018). New advances in molecular genetic field such as application of DNA markers in plant selection, quantitative trait locus mapping, and genetic transformation have provided insight for breeders to produce new rice varieties with durable bacterial leaf blight 
disease resistance. We screened the $x a 21, x a 13, x a 5, x a 4$, and $x a 2$ resistance genes in 10 local Malaysian rice varieties based on high agronomic performance and to help provide fundamental information for the development of new durable resistant varieties that can withstand bacterial leaf blight using the gene pyramiding approach.

\section{MATERIAL AND METHODS}

\section{Plant material and research design}

The study consists of Malaysia's five breeding lines (MR84, MR303, MR307, MR297, MR219), four mutant lines (NMR151, NMR152, Mahsuri Mutant, Tongkat Ali), and one landrace cultivar (Pongsu Seribu 2) obtained from GeneBank of Malaysian Agricultural Research and Development Institute (MARDI). Towuti and Tetep varieties act as a positive check (resistant) while MR284 was used as negative check (susceptible) in this study. Seed germination was examined by incubating the seeds at $28^{\circ} \mathrm{C}$ in the dark for 4 days. Plastic trays $(36 \mathrm{~cm} \times 23 \mathrm{~cm} \times 10 \mathrm{~cm})$ were used to transfer the germinated seeds and each seed was sown with ten replicates in ten-centimeter rows per tray. Replication was carried out three times in a completely randomized design. The plants were grown at 25$30^{\circ} \mathrm{C}$ for 45 days (active tillering phase) supplemented with standard amount of fertilizer in a greenhouse following the method of Fillipi and Prabu (2001).

\section{DNA extraction}

Fresh and young leaves of three weeks old were collected from the 13 transplanted local rice varieties. Leaves were swabbed with $70 \%$ ethanol to avoid any contamination from foreign DNA or spores. $1 \mathrm{~mL}$ of pre-heated CTAB (Cetyltrimethylammonium bromide) buffer were transferred in $1.2 \mathrm{~mL}$ collection microtubes containing 3-mm tungsten beads. Forty $\mathrm{mg}$ of leaves were disrupted and homogenized into a fine powder at $30 \mathrm{~Hz}$ for 4 min using QIAGEN TissueLyser (QIAGEN TissueLyser II, QIAGEN, USA). Extraction of genomic DNA were then isolate using fine powdered leaf sample following method by Doyle and Doyle (1990). Nano-drop spectrophotometry (PerkinElmer, Singapore) was used to quantify the DNA and $1.0 \%$ agarose gel was used to visualize the DNA quality.

\section{PCR amplification with SSR markers}

SSR and STS markers that were reported to be previously linked with $x a$ gene were employed to identify the presence of BLB resistance gene in local rice varieties. Amplification of Polymerase Chain Reaction (PCR) was performed following the method mentioned by McCouch et al. (2002). A $25 \mathrm{Ml}$ volume of mixture PCR consisting of $5 \mu \mathrm{L}$ of $5 \times$ PCR buffer, $5 \mu \mathrm{L}$ of $10 \mathrm{mmol} \mathrm{1-1} \mathrm{dNTPs} \mathrm{(Promega,} \mathrm{Madison,} \mathrm{WL,} \mathrm{USA),} 0.1 \mu \mathrm{L}$ of 1.5 units of Taq DNA polymerase (Promega, Madison, WL, USA), $10.4 \mu \mathrm{L}$ of sterile ultrapure deionized water, $2 \mu \mathrm{L}$ of $50 \mathrm{ng}$ DNA template, and $4.0 \mu \mathrm{L}$ of 10 pmol $\mu \mathrm{L}$ of forward and reverse primers was prepared. Markers Xa13, RM122 (STS), RM317, RM224, pTA-248 (STS) were used to identify $x a$ gene (Table 1). Sterile deionized water acted as a negative-DNA control. PCR amplification was performed following a program of 30 cycles of $94^{\circ} \mathrm{C}$ for $1 \mathrm{~min}$ at denaturation, $1 \mathrm{~min}$ at $55^{\circ} \mathrm{C}$ for annealing, $72^{\circ} \mathrm{C}$ for $2 \mathrm{~min}$ for 
polymerization, $72^{\circ} \mathrm{C}$ for $7 \mathrm{~min}$ for final elongation and allow to fast cooling at $4{ }^{\circ} \mathrm{C}$ prior to analysis. Molecular Imager ${ }^{\circledR}$ (GelDocTM XR, Bio-Rad) was used to visualize the PCR product. Alpha Ease Fc5.0 software was used to calculate the molecular weights of different alleles.

\section{Pathogenicity test}

The culture of Xoo (strain MXO 1410) was obtained from the pathology laboratory, MARDI Seberang Perai, Malaysia and was sub cultured on peptone sucrose agar medium containing $2 \%$ sucrose $(\mathrm{w} / \mathrm{v}), 2.5 \%$ peptone $(\mathrm{w} / \mathrm{v}), 0.05 \% \mathrm{~K}_{2} \mathrm{PO}_{4}(\mathrm{w} / \mathrm{v})$, and $0.025 \%$ $\mathrm{MgSO}_{4} \cdot 7 \mathrm{H}_{2} \mathrm{O}(\mathrm{w} / \mathrm{v})$ and maintained it at $\mathrm{pH} 7.0$ (Fany and Presley, 1983). The bacterial culture was then adjusted to an OD600 of 1.0 in sterile water. Rice seedlings (fully developed leaves approximately 45 days old after transplanting) were inoculated with isolate MXO 1410 strain of Xoo by leaf clipping method. Sterilized scissors dipped in the $10^{8} \mathrm{cfu} / \mathrm{mL}$ bacterial suspension were used to cut $2-3 \mathrm{~cm}$ of leaves at the top (Kauffman et al., 1973). Phenotypic evaluation based on disease scoring were done after 21 days post inoculation following the Standard Evaluation System (SES) of the International Rice Research Institute (IRRI, 2013).

\section{Disease scoring}

For each variety, 10 plants per genotype and five leaves per plant from each replication were randomly chosen to record the disease severity. Disease reaction were adjusted based on the mean lesion length following a disease index (IRRI, 1996): highly resistant $(<1 \mathrm{~cm})$, resistant $(1-3 \mathrm{~cm})$, moderately resistant $(3-6 \mathrm{~cm})$, moderately susceptible $(6-10 \mathrm{~cm})$, and susceptible $(>10 \mathrm{~cm})$. Lesion length were calculated in the infected region of the leaf from one end to another.

Table 1. Information of polymorphic microsatellite markers linked with $x a$ for Oryza sativa used in this study.

\begin{tabular}{|c|c|c|c|c|c|}
\hline Primer & Chromosome & Forward & Reverse & $\begin{array}{l}\text { PCR } \\
\text { product }\end{array}$ & $\begin{array}{l}\text { Linked } \\
\text { gene }\end{array}$ \\
\hline Xa13 & 8 & F: GGCCATGGCTCAGTGTTTAT & R: GAGCTCCAGCTCTCCAAATG & $498 \mathrm{bp}$ & xal3 \\
\hline $\begin{array}{l}\text { RM122 } \\
\text { (STS) }\end{array}$ & 5 & $\begin{array}{l}\text { F: } \\
\text { GAGTCGATGTAATGTCATCAGTGC }\end{array}$ & $\begin{array}{l}\text { R: } \\
\text { GAAGGAGGTATCGCTTTGTTGGA }\end{array}$ & $240-230 \mathrm{bp}$ & $x a 15$ \\
\hline RM317 & 4 & F: CATACTTACCAGTTCACCGCC & $\begin{array}{l}\text { R: } \\
\text { CTGGAGAGTGTCAGCTAGTTGA }\end{array}$ & $154 \mathrm{bp}$ & $x a 2$ \\
\hline RM224 & 11 & F: ATCGATCGATCTTCACGAGG & R: TGCTATAAAAGGCATTCGGG & $160 \mathrm{bp}$ & $x a 4$ \\
\hline $\begin{array}{l}\text { pTA- } \\
248 \\
\text { (STS) }\end{array}$ & 11 & $\begin{array}{l}\text { F: } \\
\text { AGACGCGGAAGGGTGGTTCCCGGA }\end{array}$ & $\begin{array}{l}\text { R: } \\
\text { AGACGCGGTAATCGAAGATGAAA }\end{array}$ & $1100 / 925 b p$ & $x a 21$ \\
\hline
\end{tabular}

\section{RESULTS}

\section{Genotype screening for bacterial leaf blight resistance}

Microsatellites and sequence tag sites markers (Xa13, RM122, RM317, RM224, and pTA-248) were used to examine 10 local Malaysian rice varieties for resistance genes 
viz. $x a 13, x a 15, x a 2, x a 4$, and $x a 21$. These bacterial leaf blight resistance genes were identified by visualization of amplicons from PCR results near 498 bp, 240-230 bp, 154 bp, $160 \mathrm{bp}$, and 1100/925 bp, respectively. The resistant, Tetep and Towuti, and susceptible, MR284 controls were included as a checking mechanism for the respective genes. Result of genotypic screening of ten local varieties are presented in Table 2 while Figure 1 shows the banding patterns of DNA markers for BLB resistance genes. Presence of $x a 2$ gene were successfully identified in 13 rice lines including Tetep and Towuti with positive fragment amplified at 154 bp. STS marker pTA-248 and SSR marker RM224 are utilized to amplify dominant resistance genes, however, only Mahsuri Mutant rice line amplified $925 \mathrm{bp}$ fragments. Meanwhile, NMR152 and Tongkat Ali rice lines amplified $160 \mathrm{bp}$ fragment along with the control resistant variety, Towuti, indicating the presence of $x a 21$ and $x a 4$ genes. None of the amplicons specific to $x a 13$ and $x a 5$ alleles were identified, suggested all the local rice accession did not carrying this resistance gene.

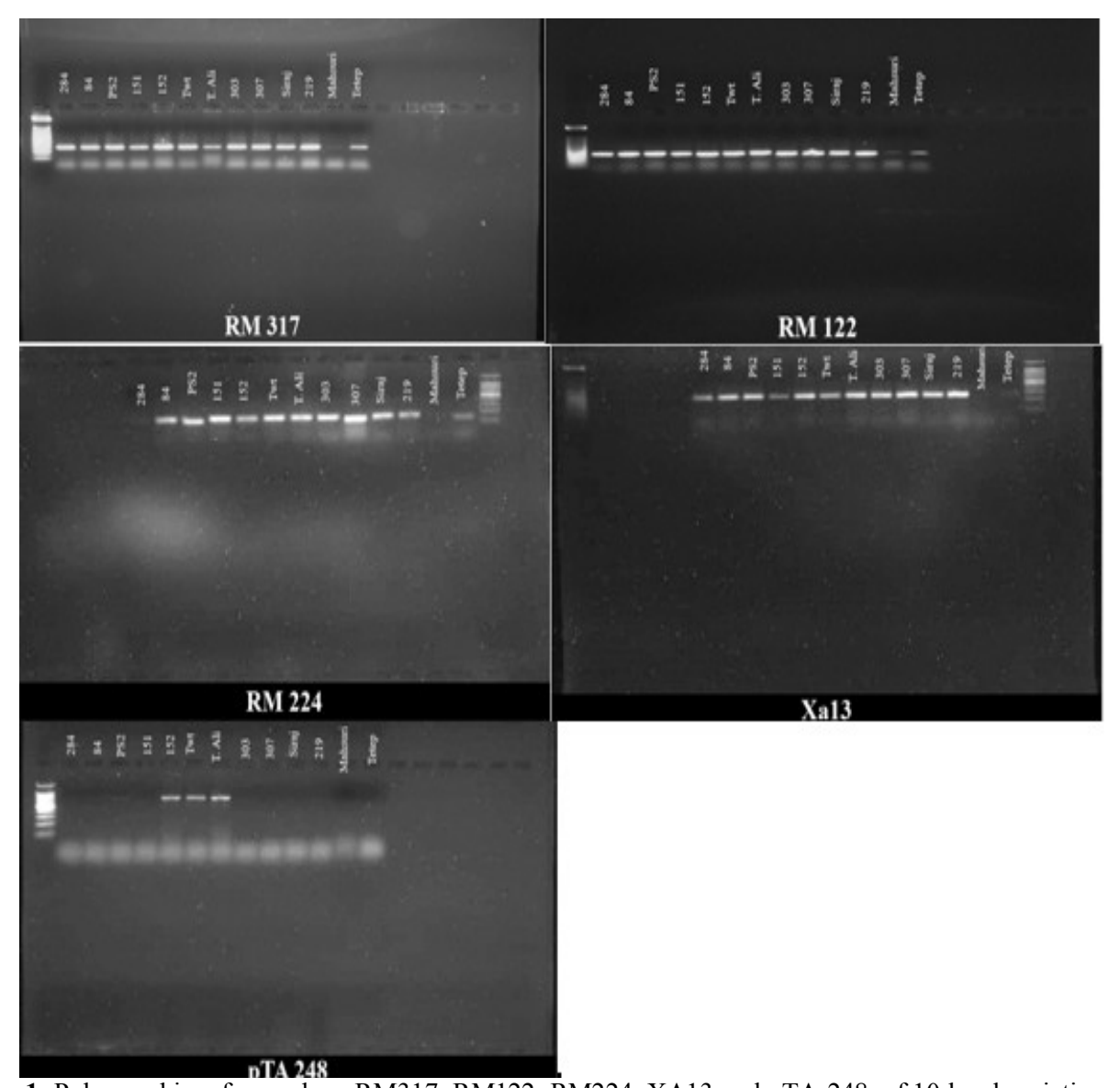

Figure 1. Polymorphism for markers RM317, RM122, RM224, XA13 and pTA-248, of 10 local varieties of rice on $1 \%$ agarose gel stained with gel star ( $\mathrm{M}=100 \mathrm{bp}$ ladder); Tetep and Towuti act as positive check (resistant), MR284 act as negative check (susceptible). 


\section{Phenotypic screening for bacterial leaf blight resistance}

Preliminary screening on bacterial leaf blight was evaluated on thirteen rice accessions along with resistant (Towuti and Tetep) and susceptible (MR219) controls against Xoo MXO 1410 isolate under greenhouse condition during 2019. At 21 days after inoculation, 3 genotypes showed resistant disease symptoms, 2 genotypes were moderately resistant, 4 genotypes were moderately susceptible, and 1 genotype was susceptible (Figure 2). Among these rice accessions, NMR152, Tongkat Ali, and Mahsuri Mutant showed the lowest disease severity while MR219 showed the highest. This symptom first visible in accession MR219 five days followed by accessions MR303 and MR297 after eight days after inoculation as compared with resistant controls (Towuti), which demonstrated the symptoms 11 days after inoculation while susceptible control MR284 displayed the symptoms after three days. Figure 3 represent the phenotypes of the three most resistant (i.e., NMR152, Mahsuri Mutant and Tongkat Ali) and the most susceptible cultivars (i.e., MR219) from the greenhouse inoculation. Lesions commonly appeared on leaf blades or leaf as yellow-orange stripes tips or water-soaked. On younger lesions, a milky dew drop was formed in the morning and turn into white lesions and mechanically injured parts of leaves as the disease progresses. Table 2 presents the results of phenotypic screening based on disease severity (diseased leaf area); the cultivars were evaluated and values were computed after inoculation with MXO 1410 strain of Xoo.

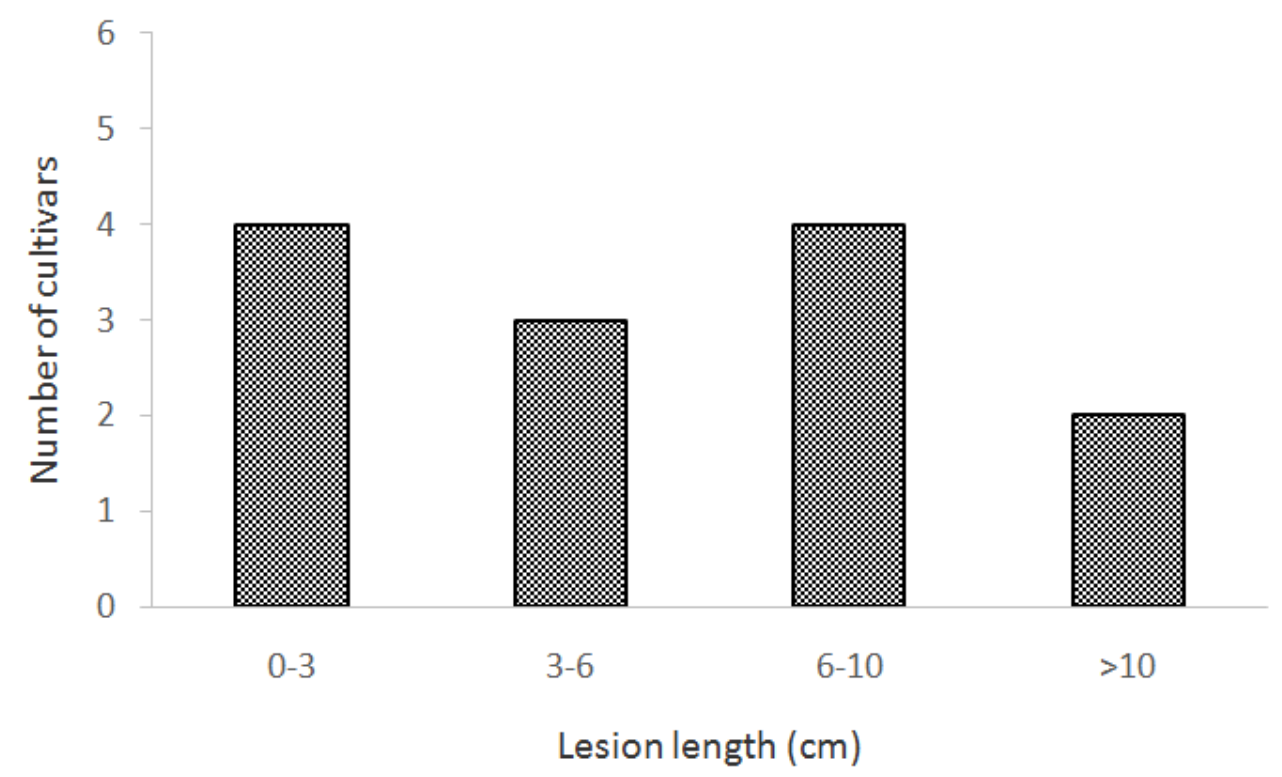

Figure 2. Distribution of bacterial blight lesion length (in $\mathrm{cm}$ ) in 13 rice cultivars including two resistant controls (Towuti and Tetep) and one susceptible control (MR284) after Xoo MXO 1410 strain inoculation. 

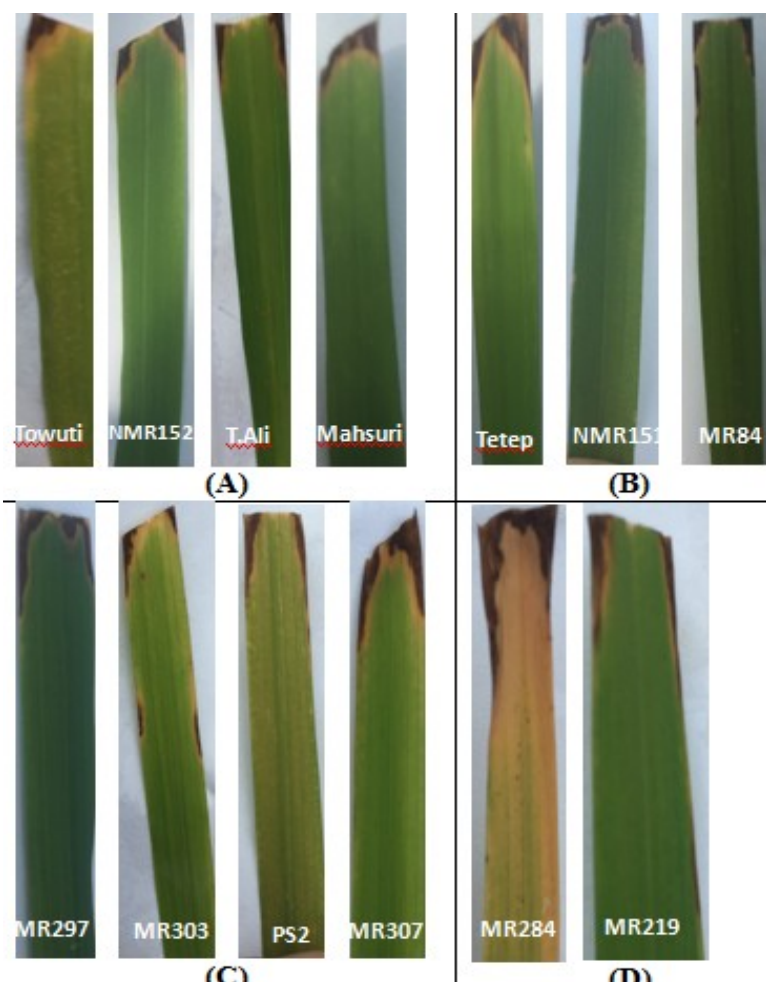

(B)
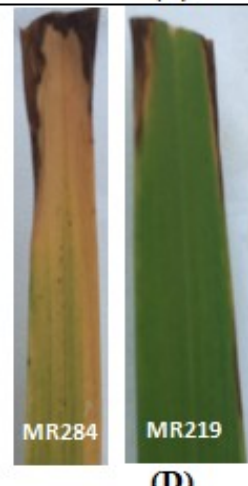

Figure 3. The effect of Xoo MXO 1410 strain inoculation on the leaf blades of 13 rice genotypes (Towuti and Tetep act as resistant controls; MR284 act as susceptible control): (A) resistant, 1-3cm; (B) moderate resistant, 3$6 \mathrm{~cm}$; (C) moderate susceptible, $6-10 \mathrm{~cm}$; (D) susceptible, $>10 \mathrm{~cm}$. The progress in disease infestation as observed on the infected leaf blades was photographed 21 days post inoculation.

Table 2. Summary of the phenotypic and genotypic screening for bacterial leaf blight resistance in 13 rice accessions.

\begin{tabular}{|c|c|c|c|c|c|c|c|c|c|}
\hline & \multirow{2}{*}{ Variety } & \multicolumn{2}{|c|}{ Disease severity } & \multirow{2}{*}{$\begin{array}{l}\text { Host } \\
\text { response }\end{array}$} & \multicolumn{5}{|c|}{ Bacterial leaf blight resistance genes } \\
\hline & & $14 \mathrm{DAI} \pm \mathrm{SD}$ & $21 \mathrm{DAI} \pm \mathrm{SD}$ & & $x a 21$ & $x a 13$ & $x a 5$ & $x a 4$ & $x a 2$ \\
\hline \multirow{3}{*}{$\begin{array}{l}\text { Resistant } \\
\text { control } \\
\text { Susceptible } \\
\text { control }\end{array}$} & Tetep & $3.08 \pm 0.405$ & $4.3 \pm 0.340$ & MR & - & - & - & - & + \\
\hline & Towuti & $1.28 \pm 0.263$ & $2.03 \pm 0.287$ & $\mathrm{R}$ & + & - & - & - & + \\
\hline & MR284 & $8.91 \pm 0.557$ & $12.41 \pm 1.038$ & $\mathrm{~S}$ & - & - & - & - & + \\
\hline 1 & MR219 & $6.43 \pm 0.709$ & $10.97 \pm 1.38$ & $\mathrm{~S}$ & - & - & - & - & + \\
\hline 2 & MR84 & $2.83 \pm 0.361$ & $5.21 \pm 0.487$ & MR & - & - & - & - & + \\
\hline 3 & MR303 & $5.22 \pm 0.556$ & $7.55 \pm 0.821$ & MS & - & - & - & - & + \\
\hline 4 & MR307 & $5.91 \pm 1.005$ & $7.91 \pm 1.211$ & MS & - & - & - & - & + \\
\hline 5 & MR297 & $5.11 \pm 0.446$ & $7.6 \pm 0.804$ & MS & - & - & - & - & + \\
\hline 6 & NMR151 & $3.26 \pm 0.332$ & $4.96 \pm 0.411$ & MR & - & - & - & - & + \\
\hline 7 & NMR152 & $1.44 \pm 0.325$ & $2.26 \pm 0.272$ & $\mathrm{R}$ & + & - & - & - & + \\
\hline 8 & $\begin{array}{l}\text { Mahsuri } \\
\text { Mutant }\end{array}$ & $1.64 \pm 0.239$ & $2.51 \pm 0.305$ & $\mathrm{R}$ & - & - & - & + & + \\
\hline 9 & Tongkat Ali & $1.45 \pm 0.371$ & $2.33 \pm 0.205$ & $\mathrm{R}$ & + & - & - & - & + \\
\hline \multirow[t]{2}{*}{10} & $\begin{array}{l}\text { Pongsu Seribu } \\
2\end{array}$ & $5.25 \pm 0.555$ & $8.40 \pm 0.324$ & MS & - & - & - & - & + \\
\hline & & & & & 23.08 & 0 & 0 & 7.69 & 100 \\
\hline
\end{tabular}

Scoring data for bacterial leaf blight resistance gene in rice, presence (+) or absence (-) of resistance genes linked to SSR and STS markers. DAI: Days after inoculation, SD: standard deviation, R: resistant, MR: moderately resistant, MS: moderately susceptible, S: Susceptible. 


\section{DISCUSSION}

Bacterial leaf blight disease is considered the most important disease causing yield loss in rice. To tackle this issue and avoid possible epidemics, several strategies have been proposed to constrain the evolution of pathogen populations. Host-plant resistance is considered as a significant control strategy. Therefore, information of varietal resistance is vital to develop cultivars with durable resistance. We examined 13 cultivars (including Towuti and Tetep for resistant check and MR284 for susceptible check) to screen for resistance to Xoo race MXO1410 strain, the causative agent of bacterial leaf blight. The MXO1410 strain of Xoo is the most aggressive and produces large lesions; it is widely used to screen rice cultivars in Malaysia as it provokes a wide range of host responses. Experiments were conducted in a greenhouse throughout November 2019.

Greenhouse evaluation revealed the different reactions of bacterial leaf blight expression of the rice genotypes due to inoculation. These reactions indicated the different characteristics of cultivars. None of the rice accessions were observed as being highly resistant. This might result in occurrence of aggressiveness and high virulence of the Xoo MXO1410 strain. Similarly, a wide range of responses of genotypes to Xoo have been observed and reported (Singh et al., 2015; Fred et al., 2016; Sombunjitt et al., 2017; Acharya et al., 2018). Plants are subjected to a wide range of environmental stresses during their growth and development stages. Plants being sessile in nature will encounter numerous defense mechanisms. Plant defense pathways involve a number of signaling compounds to protect themselves against attack by herbivorous insects and microbial pathogens (Koornneef and Pieterse, 2008).

In this study, rice cultivars Tongkat Ali, NMR152, and Mahsuri Mutant with dominant resistance genes, $x a 21$ and $x a 4$ which were combined with another recessive gene, $x a 2$ were resistant to the Xoo strain. These results from our analysis consistent with the reports made by Sabar et al. (2017) and Chukwu et al. (2019). According to Suh et al. (2013), incorporating the resistance genes Xa4, xa21 conferred a durable resistance compare to the lines with one resistance gene. Pradan et al. (2015) reported that three-gene combinations found to be the most productive which Xa21 contributes the durable resistance from susceptible juvenile stage to complete resistance at adult plant stage. Bacterial leaf blight resistance gene xa21 commonly utilized resistance genes in many rice breeding programs and it confers durable resistance in many popular rice cultivars (Nguyen et al., 2018). Therefore, these rice cultivars potentially useful genetic resource for rice breeding programs. They will accelerate breeding efforts for the development of BLB resistant rice cultivars through pyramiding approach using marker assisted selection.

Genotypes identified with the presence of only Xa2 gene by SSR marker (MR297, MR307, MR303 and PS2) were classified as moderately susceptible, whereas MR219 was susceptible. Tetep as resistant check also demonstrated moderately resistant phenotype against MXO1410 Xoo isolates. According to Panwar et al. (2018), avirulent genes in bacteria exhibit the specificity for resistance gene in the rice plants. Some resistance gene expressed and effective at different growth stage. Some genes confer a broad-spectrum disease resistance against two or more types of pathogen while other on different races of Xoo. These were observed in this study where eventhough the rice cultivars consist of resistance gene $x a 2$, most of them were rendered susceptible against Xoo race MXO1410 strain; similar to the case of Jumli Marsh rice (Acharya et al., 2018). 
Molecular characterization showed that none of our germplasm carried xal3 and $x a 5$ genes in our findings. Result was aligned with Yugander et al. (2018) by using 38 of modern cultivated Malaysian varieties. Singh et al. (2015) also stated that none of the 25 landraces studied had xal3 genes. According to Lore et al. (2011), the resistance gene xal3, was originally identified from a land race BJ1 from the Indian subcontinent, and it is exhibiting a wide spectrum of resistance individually or as combination with other resistance genes against multiple Xoo isolates. Therefore, it should be noted that we could not found $\mathrm{xa} 13$ gene in this study among rice accession.

We report here a new approach that is based on the widespread conventional selection with the use of information from molecular markers, facilitating breeding programs through better combination of cost, time, precision, and durability. This study has revealed useful preliminary information for selection of genotypes with durable resistance to the disease in order to prevent farm fields from epidemics. However, further studies including trials under field conditions should be undertaken.

\section{CONCLUSIONS}

We identified the $x a 4$ gene in Mahsuri mutant rice genotypes, $x a 21$ in NMR152 and Tongkat Ali mutant rice genotypes and the $x a 2$ gene in all genotypes tested. Among these, three genotypes were found to have a combination of dominant (xa21 and $x 4$ ) and recessive $(x a 2)$ gene alleles. Genotypes carrying two bacterial leaf blight resistance genes were found resistant under greenhouse conditions. These findings provide fundamental information for breeders for developing broad spectrum bacterial leaf blight resistance in rice by using a marker assisted approach.

\section{ACKNOWLEDGMENTS}

The authors are thankful to Universiti Teknologi MARA, Universiti Putra Malaysia and Agency Nuclear Malaysia for guidance and assistance. The author also would like to extend appreciation to the Ministry of Higher Education (MOHE) for providing financial aid for this research.

\section{CONFLICTS OF INTEREST}

The authors declare no conflict of interest.

\section{REFERENCES}

Acharya A, Adhikari NR, Amgain RB, Poudel A, et al. (2018). Identification of Rice Genotypes Resistant to Bacterial Leaf Blight Disease using SSR Markers. Inst. Agric. Anim. Sci. 35: 113-120.

Bharani PM. Nagarajan R, Rabindran R, Saraswathi P, et al. (2010). Bacterial leaf blight resistance genes (Xa21, xa13 and $x a 5$ ) pyramiding through molecular marker assisted selection into rice cultivars. Arch. Phytopathol. Plant Protect. 43(10): 1032-1043.

Chukwu SC, Rafii MY, Ramlee SI, Ismail SI, et al. (2019). Bacterial leaf blight resistance in rice: A review of conventional breeding to molecular approach. Mol. Biol. Rep. 46(1): 1519-1532.

DOA (2019). Department of Agriculture Malaysia: Report of bacterial blight disease in Malaysia.

Doyle JJ and Doyle JL (1990). Isolation of plant DNA from fresh tissue. Focus. 12.

Fany RC and Persley GJ (1983). Plant bacterial disease. A diagnostic Guide. Sydney-Toronto: Academic Press.

Filippi MC and Prabhu AS (2001). Phenotypic virulence analysis of Pyricularia grisea isolates from Brazilian upland rice cultivars. Pesq. Agropec. Bras. 36: 27-35. 
Fred AK, Kiswara G, Yi G and Kim KM (2016). Screening Rice Cultivars for Resistance to Bacterial Leaf Blight. $J$. Microbiol. Biotechnol. 26(5): 938-945.

Herman T, Murchie EH and Warsi AA (2015). Rice Production and Climate Change: A Case Study of Malaysian Rice. Pertanika J. Trop. Agric. Sci. 38(3): 321328

IRRI (1996). Standard Evaluation System Manual. International Rice Research Institute, Manila, Philippines, 35.

IRRI (2013). Standard Evaluation System for Rice (SES). $5^{\text {th }}$ ed. International Rice Research Institute, Manila, Philippines.

Kauffman HE, Reddy APK, Hsieh SPY and Merca SD (1973). An improved technique for evaluating resistance of rice varieties to Xanthomonas oryzae. Plant Disease Rep. 57: 537-541.

Koornneef A and Pieterse CM (2008). Cross talk in defense signaling. Plant Physiol. 146: 839-844.

Lore JS, Vikal Y, Hunjan MS, Goel RK, et al. (2018). Genotypic and Pathotypic Diversity of Xanthomonas oryzae pv. oryzae, the Cause of Bacterial Blight of Rice in Punjab State of India. J. Phytopathol.159(7-8):479 - 487.

McCouch SR, Teytelman L, Xu Y and Lobos KB (2002). Development and mapping of 2240 new SSR markers for rice (Oryza sativa L.). DNA Res. 9: 199-207.

MOA (2018). Malaysia targets $80 \%$ rice self-sufficiency by 2022. Rice supply demand scenarios for Malaysia. Food and Agriculture Organization of the United Nation

Nadeem MA, Nawaz MA, Shahid MQ, Doyan Y, et al. (2018). DNA molecular markers in plant breeding: current status and recent advancements in genomic selection and genome editing, Biotechnol. Biotechnol. Equip. 32(2): 261-285.

Nguyen HT, Vu QH, Van Mai T, Nguyen TT, et al. (2018). Marker-Assisted Selection of Xa21 Conferring Resistance to Bacterial Leaf Blight in Indica Rice Cultivar LT2. Rice Sci. 25(1): 52-56.

Nor'Aishah H, Abdul Rahim H, Khairuddin AR, Sobri H, et al. (2013). Assessment of Purity of F1 Plants Derived from the Cross of MR264 and Pongsu Seribu 2 Using Microsatellite Markers. Int. Proc. Chem. Biol. Environ. Eng. 57: 15 .

Panwar BS, Trivadi R, Ravikran R, Ram C, et al. (2017). Molecular Marker-based Screening for Bacterial Leaf Blight Resistance Genes in Landraces and Cultivars of Rice in Gujarat. Indian J. Plant Genet. Resour. 31(1): 51-56.

Patra BC, Soham R and Ngangkham TM (2018). Genetic and Genomic Resources for Grain Cereals Improvement 2016, Pages 1-80 Academic Press Indian J. Plant Genet. Resour. 31(1): 1- 8.

Pradan SK, Deepak Kumar N, Soumya M, Lambodar B, et al. (2015). Pyramiding of three bacterial blight resistance genes for broad-spectrum resistance in deep water rice variety, Jalmagna. Rice. 8: 19-33.

Rajamoorthy Y, Abdul Rahim K and Munusamy S (2015). Rice Industry in Malaysia: Challenges, Policies and Implications. Procedia Economics and Finance.13(2): 861-867.

Sabar MT, Bibi T, Farooq HU, Haider Z, et al. (2016). Molecular screening of rice (Oryza sativa L.) germplasm for Xa4, $x a 5$ and Xa21 bacterial leaf blight (BLB) resistant genes using linked marker approach. Afr. J. Biotechnol. 15(41): 2317-2324.

Singh AK, Dharmaji E, Nayak R, Singh PK, et al. (2015). Identification of bacterial leaf blight resistance genes in wild rice of eastern India. Turk J. Bot. 39: 1060-1066

Sombunjitt S, Tanee S, Chatuporn K and Vipa H (2017). Searching for and analysis of bacterial blight resistance genes from Thailand rice germplasm. Agric. Nat. 51(5): 365-375.

Suh JP, Jeung JU, Noh TH, Cho YC, et al. (2013). Development of breeding lines with three pyramided resistance genes that confer broad-spectrum bacterial blight resistance and their molecular analysis in rice. Rice. 6: 5-10.

Tagami Y and Mizukami T (1962). Historical review of researches on bacterial leaf blight of rice caused by Xanthomonas oryzae (Uyeda et Ushiyama) Dowson. Special report of the plant diseases and insect pest forecasting service No. 10. Plant protection Division, Ministry of Agriculture and Forestry, Tokyo, Japan.

Vikal Y and Bhatia D (2017). Genetics and genomics of bacterial blight resistance in rice. In: Advances in international rice research, Chap 10. London: IntechOpen.

Wahab GW (2018). Malaysia Grain and Feed Annual. USDA Foreign Agricultural Service Gain Report Number: MY8002.

Yugander A, Sundaram RM, Singh K, Ladhalakshmi D, et al. (2018). Incorporation of the novel bacterial blight resistance gene Xa38 into the genetic background of elite rice variety Improved Samba Mahsuri. PLoS One. 13(5): $\mathrm{e} 0198260$.

Zhou XG (2019). Sustainable Strategies for Managing Bacterial Panicle Blight in Rice. London: IntechOpen. 